\title{
ANALISIS FAKTOR-FAKTOR YANG MEMPENGARUHI PERMINTAAN TELUR AYAM RAS DI KOTA KENDARI DAN HUBUNGANNYA DENGAN KEBERDAYAAN PETERNAK
}

\author{
An Analysis of Factors Affecting Demands for Broiller Chicken Eggs in Kendari City \\ and its Correlation With Breeders Empowerment
}

\author{
${ }^{1}$ Ine Fausayana, ${ }^{2}$ Marwan Akbar Marzuki \\ ${ }^{1}$ Program Studi Magister Agribisnis Universitas Halu Oleo \\ ${ }^{2}$ Alumni S2 Program Studi Magister Agribisnis Universitas Halu Oleo
}

\begin{abstract}
This study aimed to determine : 1). Factors that affect demand for broiler chicken eggs in Kendari city, 2) The empowerment of broiler breeders, 3) The correlation between demands for broiler chicken eggs and the empowerment of broiler breeders. The study employed an associative (cause-effect) design. Simple of chicken eggs consumers were determine purposively (purposive sampling) involving 50 consumers of broiler chicken eggs, whereas breeders empowerment was sample by using a census / total sampling method, thereby including all 5 breeders of broiler chicken. Data were collected by administering questioneair and study document. The data were analyzed by performing a descriptive statistical analysis and multiple linear regression. Result of the study concluded that : 1) consumers taste price of broiler chicken eggs, price of subtitusing goods, consumers, income, and the number of people and household were among the factors which collectively had a significant effect on the demand for broiler chicken eggs, 2) breeders of broiler chicken habe been increasingly empowered not only in the aspects of changes in worker, capital, productions but also income and profits, 3) demand for broiler chicken eggs had a positive correlations to the empowerment of chicken farmers, althougt the correlations only satisfied a very weak criteria.
\end{abstract}

Keywords : Breeders, broiler chicken eggs, demand, , Factors affecting, empowerment.

\begin{abstract}
ABSTRAK
Penelitian ini bertujuan untuk mengetahui: 1) Faktor-faktor yang mempengaruhi permintaan telur ayam ras di Kota Kendari. 2) Keberdayaan peternak ayam ras, 3) Hubungan permintaan telur ayam ras dengan keberdayaan peternak ayam ras. Rancangan penelitian adalah penelitian asosiatif (sebab akibat). Sampel penelitian untuk konsumen ayam ras ditentukan secara sengaja (purposive sampling) sebanyak sebanyak 50 orang konsumen telur ayam ras, keberdayaan peternak menggunakan metode sensus/total sampling yaitu mengambil seluruh peternak ayam ras yaiitu 5 orang. Teknik pengumpulan data menggunakan angket dan studi dokumen. Analisis yang digunakan adalah analisis statistik deskriptif dan regresi linear berganda. Hasil penelitian menyimpulkan bahwa: 1) Faktor selera konsumen, harga telur ayam ras, harga barang pengganti/ tahu, pendapatan konsumen dan jumlah anggota keluarga secara bersamaan berpengaruh signifikan terhadap permintaan telur ayam ras, 2) Peternak ayam ras semakin meningkat keberdayaannya baik dalam aspek perubahan tenaga kerja, modal, produksi, pendapatan maupun keutungan. 3) Permintaan telur ayam ras berhubungan secara positif dengan keberdayaan peternak ayam ras walaupun hubungan tersebut termasuk dalam kriteria hubungan sangat lemah.
\end{abstract}

Kata kunci: Peternak, telur ayam ras, permintaan, faktor-faktor yang berpengaruh, keberdayaan 


\section{PENDAHULUAN}

Telur sebagai salah satu produk ternak unggas mengandung protein yang sangat berperan dalam tubuh manusia karena protein berfungsi sebagai zat pembangun yaitu bahan pembentuk jaringan baru di dalam tubuh, zat pengatur yaitu mengatur berbagai sistem di dalam tubuh.. Adapun kontribusi protein asal ternak tersebut sebesar $25,50 \%$ dari total kebutuhan minimal untuk orang Indonesia yaitu 1,158 gr per kapita per hari. Namun tingkat konsumsinya masih di bawah standar Widya Pangan dan Gizi tahun 1998 yaitu 6gr per kapita per hari (Fitrini, Andri dan A.N. Yanti, 2006).

Hasil penelitian Hardinsyah dan Arifin dalam Kemalawaty (2008) menyimpulkan bahwa semakin tinggi pendapatan cenderung semakin tinggi konsumsi pangan hewani. Artinya peningkatan pendapatan akan meningkatkan daya beli terhadap konsumsi pangan hewani.

Berdasarkan data yang diperoleh Dinas Perindustrian, Perdagangan dan Koperasi permintaan terhadap telur ayam ras di Kota Kendari mengalami fluktuasi, hal ini dapat dilihat pada Tabel berikut :
Tabel 1. Konsumsi Telur Ayam Ras di Kota Kendari, Tahun 2005-2014

\begin{tabular}{|c|c|c|r|}
\hline No. & Tahun & $\begin{array}{c}\text { Konsumsi } \\
\text { Telur } \\
\text { Ayam Ras } \\
\text { (Kg) }\end{array}$ & $\begin{array}{c}\text { Laju } \\
\text { Pertumbuhan } \\
(\%)\end{array}$ \\
\hline 1 & 2005 & 761.525 & - \\
2 & 2006 & 764.621 & 0,41 \\
3 & 2007 & 874.109 & 14,32 \\
4 & 2008 & 878.173 & 0,46 \\
5 & 2009 & 748.908 & $-14,72$ \\
6 & 2010 & 749.064 & 0,02 \\
7 & 2011 & 848.803 & 13,32 \\
8 & 2012 & 891.819 & 5,07 \\
9 & 2013 & 884.741 & $-0,79$ \\
10 & 2014 & 873.490 & $-1,27$ \\
\hline
\end{tabular}

Sumber: Dinas Perindakkop, Tahun 2015

Tabel 1. menunjukkan bahwa jumlah konsumsi telur ayam ras mengalami fluktuasi dari tahun ke tahun. Dimana pada tahun 2006 jumlah konsumsi telur ayam ras meningkat $0,41 \%$ demikian pula pada tahun 2007 meningkat sebesar 14,32\%. Namun pada tahun 2009 mengalami penurunan sebesar 14,72\% pada tahun 2011 permintaan kembali naik secara signifikan yaitu sebesar $13,32 \%$. Walaupun demikian pada tahun 2014 terjadi penurunan cukup signifikan yaitu sebesar 1,27\%. Adanya fluktuasi dan penurunan jumlah konsumsi telur ayam ras tersebut, selain tidak mengikuti peningkatan pendapatan per kapita penduduk kota Kendari juga tidak sejalan dengan peningkatan produksi telur ayam ras tiap tahun.

Banyaknya konsumsi masyarakat terhadap telur ayam ras merupakan 
cerminan dari kondisi permintaan masyarakat terhadap telur ayam ras.

Faktor-faktor yang mempengaruhi permintaan adalah harga barang itu sendiri, harga barang lain yang terkait, tingkat pendapatan per kapita, selera atau kebiasaan, jumlah anggota keluarga, perkiraan harga dimasa mendatang, distribusi pendapatan serta usaha-usaha produsen meningkatkan penjualan Prathama (2010).

Disamping itu, juga didukung beberapa hasil penelitian sebelumnya yaitu yang dilakukan oleh Fitrini, Andri dan A.N. Yanti (2006), Hastang, Veronica Sri Lestari, Arie Prayudi (2011) bahwa faktor-faktor tersebut berpengaruh secara signifikan terhadap permintaan.

Terkait dengan faktor-faktor yang mempengaruhi permintaan telur ayam ras tersebut, maka yang dimaksud dengan harga telur ayam ras adalah nilai rupiah pengorbanan konsumen untuk mendapatkan sejumlah telur ayam ras. Harga barang pengganti dalam hal ini adalah tahu, merupakan nilai rupiah pengorbanan konsumen untuk mendapatkan sejumlah tahu yang diinginkan. Tahu dijadikan sebagai bahan pengganti karena mengandung protein yang sangat tinggi.

Permintaan telur ayam ras sesungguhnya merupakan cerminan dari jumlah telur ayam ras yang berhasil dijual oleh peternak ayam ras. Dengan demikian, maka permintaan pasti berkaitan dengan keberdayaan peternak ayam ras itu sendiri. Keberdayaan peternak adalah kemampuan peternak ayam ras dalam memperdayakan usahanya yang tercermin pada perubahan produksi telur ayam ras, pendapatan/ hasil penjualan, tenaga kerja, modal dan perubahan keuntungan. Perubahan tersebut dapat diketahui dengan membandingkan kondisi masa lalu dengan kondisi saat ini.

\section{METODE PENELITIAN}

\section{Kerangka Konseptual Dan Hipotesis}

Berdasarkan kajian empiris dan kajian teoritis maka kerangka konseptual yang mendasari penelitian ini adalah bahwa permintaan telur ayam ras dipengaruhi oleh beberapa faktor. Faktor-faktor dimaksud adalah selera konsumen, harga telur ayam ras, harga barang pengganti (tahu), pendapatan konsumen, dan jumlah anggota keluarga.

Permintaan sesungguhnya merupakan cerminan dari jumlah telur ayam ras yang berhasil dijual oleh peternak ayam ras. Dengan demikian, maka permintaan pasti berkaitan dengan keberdayaan peternak ayam ras itu sendiri. Keberdayaan peternak adalah kemampuan peternak ayam ras dalam memperdayakan usahanya yang tercermin pada perubahan tenaga kerja, modal, produksi telur ayam ras, pendapatan/ hasil penjualan dan perubahan 
keuntungan (sumber: kompilasi penulis). Perubahan tersebut dapat diketahui dengan membandingkan kondisi masa lalu dengan kondisi saat ini.

\section{Hipotesis Penelitian}

1. Faktor selera konsumen, harga telur ayam ras, harga barang pengganti (tahu), pendapatan perkapita konsumen, serta jumlah anggota keluarga berpengaruh signifikan terhadap permintaan telur ayam ras di Kota Kendari.

2. Keberdayaan peternak ayam ras di Kota Kendari mengalami peningkatan

3. Terdapat hubungan yang erat antara permintaan telur ayam ras dengan keberdayaan peternak ayam ras di Kota Kendari.

\section{Rancangan Penelitian}

Rancangan penelitian ini adalah penelitian asosiatif (sebab akibat).

\section{Obyek dan Waktu Penelitian}

Obyek penelitian ini adalah permintaan telur ayam ras. Waktu pelaksanaan penelitian 4 bulan

\section{Populasi dan Sampel}

\section{1) Populasi}

Populasi penelitian ini terbagi dua yaitu konsumen telur ayam ras dan peternak ayam ras yang ada di wilayah Kota Kendari. Untuk konsumen telur ayam ras jumlahnya belum diketahui secara pasti (invinitive). Sedangkan untuk peternak ayam ras sebanyak 5 (lima) orang peternak dengan rincian di Kecamatan Wua-Wua 1 orang peternak, Bonggoeya 2 orang peternak, serta Kecamatan Baruga 2 orang peternak (Sumber : Dinas Pertanian dan Kehutanan Kota Kendari, Tahun 2015).

\section{2) Sampel}

Sampel penelitian untuk konsumen ayam ras ditentukan secara sengaja (purposive sampling) sebanyak sebanyak 50 orang konsumen telur ayam ras. Hal ini didasarkan pada pendapat Ferdinand Agusty (2005) bahwa ukuran sampel minimum adalah sebanyak 5-10 kali observasi dari setiap estimate parameter (indikator). Pada analisis faktor-faktor yang mempengaruhi permintaan terdapat lima faktor sehingga ditetapkan sampel sebanyak 50 konsumen telur ayam ras. Sedangkan pada keberdayaan peternak penentuan sampelnya menggunakan metode sensus/total sampling yaitu mengambil seluruh peternak ayam ras yaitu 5 orang menjadi sampel penelitian.

\section{Jenis dan Sumber Data}

\section{1) Jenis Data}

Jenis data yang digunakan dalam penelitian ini terdiri dari data kuantitatif dan data kualitatf.

\section{2) Sumber Data}

Sumber data dalam penelitian ini yaitu data primer dan data sekunder.

\section{Teknik Pengumpulan Data}


Pengumpulan data dalam penelitian ini menggunakan teknik kuesioner dan studi dokumen.

\section{Prosedur Pengolahan Data}

Prosedur pengolahan data yaitu editing, tabulasi dan interpretasi

\section{Teknik Analisis Data}

1. Untuk mengetahui pengaruh dari masing-masing faktor (harga telur ayam ras, harga barang pengganti/ tahu, pendapatan perkapita, selera konsumen dan jumlah anggota keluarga) terhadap permintaan telur ayam ras digunakan analisis regresi linear berganda, dengan formulasi sebagai berikut:

$$
\begin{aligned}
Y= & \beta 0+\beta 1 X 1+\beta 2 X 2+\beta 3 X 3+\beta 4 \\
& X 4+\beta 5 X 5+\text { Ui (Gujarati, 2011). }
\end{aligned}
$$

Keterangan:

$\mathrm{Y}=$ Jumlah permintaan telur ayam ras $(\mathrm{Kg})$

$$
\begin{aligned}
X_{1}= & \text { Selera konsumen (persepsi } \\
& \text { senang dan tidak senang) }
\end{aligned}
$$

$\mathrm{X}_{2}=$ Harga telur ayam ras $(\mathrm{Rp} / \mathrm{kg})$

$\mathrm{X}_{3}=$ Harga barang pengganti /Tahu (Rp/kg)

$\mathrm{X}_{4}=$ Pendapatan perkapita (Rp/Bulan)

$\mathrm{X}_{5}=$ Jumlah anggota keluarga (orang)

$\beta 0=$ Nilai konstanta

$\mathrm{Ui}=$ Faktor eror

$\beta 1 \beta 2 \beta 3 \beta 4 \beta 5=$ Koefisien regresi

1. Untuk mengetahui sigifikansi pengaruh masing-masing variabel secara parsial digunakan uji t.
Kriteria pengujian hipotesis ditentukan sebagai berikut:

1. Jika $t_{\text {sig }} \leq 0,05$ maka terdapat pengaruh yang signifikan

2. Jika $t_{\text {sig }}>0,05$ maka terdapat pengaruh yang tidak signifikan

Disamping itu digunakan uji $F$ (pengaruh simultan) sekaligus mendeteksi kelayakan model (model fit) dengan memperhatikan nilai signifikan F. Jika $F_{\text {sig }} \leq 0,05$ maka model dinyatakan fit/ terdapat pengaruh signifikan secara simultan. Sebaliknya jika $F_{\text {sig }}>$ 0,05 maka model dinyatakan tidak fit.

Sebelum melakukan analisis regresi linear berganda juga dilakukan uji asumsi klasik sebagai syarat dalam penerapan analisis regresi, yaitu:

a. Uji normalitas

Berdasarkan hasil uji
normalitas data, menunjukkan
bahwa data terdistribusi normal yang dapat dilihat dari :

1) Histogram yaitu berbentuk lonceng.

2) Normal P-P Plot regression standardized menunjukkan keberadaan titik-titik disekitar garis pada skater plot.

3) Nilai kolmograv-smirnov sebesar 1,063 dengan nilai asymp sig (2tailed) sebesar 0,208 > 0,05.

b. Uji multikolineritas 
Berdasarkan hasil uji multikolineritas menunjukkan bahwa antar variabel independen tidak terjadi multikolineritas hal ini ditujukkan dengan nilai VIF untuk selera konsumen $\left(X_{1}\right)=1,113<10$, untuk harga telur ayam ras $\left(X_{2}\right)=$ $1,934<10$, untuk harga barang pengganti/ tahu $\quad\left(X_{3}\right)=2,024 \leq$ 10, untuk pendapatan konsumen $\left(X_{4}\right)=6,944<10$ serta untuk jumlah anggota keluarga $\left(X_{5}\right)=7,143<10$.

c. Uji linearitas

Berdasarkan hasi uji linearitas menunjukkan bahwa asumsi linearitas terpenuhi (kecuali variabel selera konsumen). Dimana hubungan antara selera konsumen $\left(\mathrm{X}_{1}\right)$ dengan permintaan (Y) ditunjukkan dengan nilai signifikan $0,796>0,05$. Hal ini disebabkan karena selera merupakan data persepsi. Sedangkan hubungan antara harga telur ayam ras $\left(X_{2}\right)$ dengan permintaan ( $\mathrm{Y}$ ) ditunjukkan dengan nilai signifikan 0,000<0,05. Hubungan antara harga barang pengganti/ tahu $\left(\mathrm{X}_{3}\right)$ dengan permintaan $(Y)$ ditunjukkan dengan nilai signifikan $0,000<0,05$. Hubungan antara pendapatan konsumen $\left(\mathrm{X}_{4}\right)$ dengan permintaan (Y) ditunjukkan dengan nilai signifikan $0,014>0,05$ serta hubungan antara jumlah anggota keluarga $\left(\mathrm{X}_{5}\right)$ dengan permintaan $(\mathrm{Y})$ ditunjukkan dengan nilai signifikan $0,007>0,05$.

2. Untuk menganalisis kerberdayaan peternak ayam ras di Kota Kendari digunakan analisis deskriptif kuantitatif yaitu menganalisis perubahan yang terjadi dari aspek tenaga kerja, modal, produksi telur ayam ras, pendapatan/hasil penjualan dan perubahan keuntungan, dengan cara membandingkan kondisi tiga tahun yang lalu dan kondisi sekarang. Juga diperkuat dengan analisis uji beda (paired t-test) melalui program aplikasi SPSS versi 21.0 .

3. Untuk mengetahui hubungan antara permintaan telur ayam ras dengan keberdayaan peternak digunakan analisis deskriptif kualitatif yaitu menjelaskan secara tekstual tentang keterkaitan antara permintaan telur ayam ras dengan keberdayaan peternak ayam ras. Juga ditunjang dengan analisis koefisien korelasi product moment melalui program aplikasi SPSS versi 21.0. 
HASIL PENELITIAN DAN PEMBAHASAN

Deskripsi Variabel Penelitian

1) Selera Konsumen

Tabel 2. Selera Konsumen Terhadap Telur Ayam Ras

\begin{tabular}{|l|l|c|c|}
\hline No. & $\begin{array}{l}\text { Selera } \\
\text { Konsumen } \\
\text { (Persepsi } \\
\text { Kesukaan) }\end{array}$ & $\begin{array}{c}\text { Frekuens } \\
\text { i } \\
\text { (Orang) }\end{array}$ & $\begin{array}{c}\text { Persenta } \\
\text { se } \\
\text { (\%) }\end{array}$ \\
\hline 1 & Sangat suka & 46 & 92,00 \\
2 & Biasa saja & 4 & 8,00 \\
\hline \multicolumn{2}{|l|}{ Jumlah } & $\mathbf{5 0}$ & $\mathbf{1 0 0 , 0 0}$ \\
\hline
\end{tabular}

Sumber: Data Primer, Tahun 2015.

2) Permintaan Telur Ayam Ras

Tabel 3. Permintaan Telur Ayam Ras

\begin{tabular}{|l|l|c|c|}
\hline No. & $\begin{array}{l}\text { Permintaan } \\
(\mathbf{K g})\end{array}$ & $\begin{array}{c}\text { Frekuensi } \\
\text { (Orang) }\end{array}$ & $\begin{array}{c}\text { Persent } \\
\text { ase (\%) }\end{array}$ \\
\hline 1 & $3-54$ & 31 & 62,00 \\
2 & $55-106$ & 10 & 20,00 \\
3 & $107-158$ & 9 & 18,00 \\
\hline \multicolumn{2}{|l|}{ Jumlah } & $\mathbf{5 0}$ & $\mathbf{1 0 0 , 0 0}$ \\
\hline
\end{tabular}

Sumber: Data Primer, Tahun 2015.

\section{3) Harga Telur Ayam Ras}

Tabel 4. Harga Telur Ayam Ras

\begin{tabular}{|l|l|c|c|}
\hline No. & $\begin{array}{l}\text { Harga } \\
\mathbf{( R p / K g )}\end{array}$ & $\begin{array}{c}\text { Frekuensi } \\
\text { (Orang) }\end{array}$ & $\begin{array}{c}\text { Persenta } \\
\text { se } \\
\text { (\%) }\end{array}$ \\
\hline 1 & 16.250 & 16 & 32,00 \\
2 & 17.000 & 5 & 10,00 \\
3 & 17.500 & 29 & 58,00 \\
\hline \multicolumn{2}{|l|}{ Jumlah } & $\mathbf{5 0}$ & $\mathbf{1 0 0 , 0 0}$ \\
\hline
\end{tabular}

Sumber: Data Primer, Tahun 2015.

\section{4) Harga Barang Pengganti}

Harga barang pengganti adalah nilai rupiah pengorbanan konsumen untuk mendapatkan sejumlah tahu sebagai pengganti telur ayam ras pada saat-saat tertentu yang dinyatakan dalam satuan rupiah per kilogram. Sesuai data hasil penelitian terlampir rata-rata harga tahu sebesar Rp. 8.000,- per kilogram. Khusus untuk para pedagang mendapatkan harga sebesar Rp. 7000,- per kilogram karena membeli untuk menjual kembali.

\section{5) Pendapatan}

Tabel 5. Pendapatan/ Hasil Penjualan

\begin{tabular}{|l|l|c|c|}
\hline No. & $\begin{array}{l}\text { Pendapatan } \\
\text { Rata-Rata } \\
\text { (Rp/Bulan) }\end{array}$ & $\begin{array}{l}\text { Frekuen } \\
\text { si } \\
\text { (Orang) }\end{array}$ & $\begin{array}{c}\text { Persenta } \\
\text { se } \\
(\%)\end{array}$ \\
\hline 1 & $2.845 .000-$ & 27 & 54,00 \\
2 & 5.044 .000 & 8 & 16,00 \\
3 & $5.045 .000-$ & 15 & 30,00 \\
& 7.244 .000 & & \\
& $7.245 .000-$ & & \\
\hline \multicolumn{2}{|c|}{ Jumlah } & & \\
\hline
\end{tabular}

Sumber: Data Primer, Tahun 2015.

6) Jumlah Anggota Keluarga

Tabel 6. Jumlah Anggota Keluarga

\begin{tabular}{|l|l|r|r|}
\hline No. & $\begin{array}{l}\text { Jumlah } \\
\text { Anggota } \\
\text { Keluarga }\end{array}$ & $\begin{array}{l}\text { Frekuensi } \\
\text { (Orang) }\end{array}$ & $\begin{array}{l}\text { Persenta } \\
\text { se (\%) }\end{array}$ \\
\hline 1 & $3-4$ & 24 & 48,00 \\
2 & $5-6$ & 11 & 22,00 \\
3 & $7-9$ & 15 & 30,00 \\
\hline \multicolumn{2}{|l|}{ Jumlah } & $\mathbf{5 0}$ & $\mathbf{1 0 0 , 0 0}$ \\
\hline
\end{tabular}

Sumber: Data Primer, Tahun 2015.

\section{Keberdayaan Peternak}

Tabel 7. Rekapitulasi Aspek Keberdayaan Peternak Ayam Ras

\begin{tabular}{|c|c|c|c|c|c|c|}
\hline \multirow{2}{*}{ No } & \multirow{2}{*}{$\begin{array}{c}\text { Aspek } \\
\text { Keberdayaa } \\
\text { n Pernak }\end{array}$} & \multicolumn{2}{|c|}{$\begin{array}{c}\text { Tiga Tahun yang } \\
\text { Lalu }\end{array}$} & \multicolumn{2}{|c|}{ Tahun sekarang } & \multirow{2}{*}{$\begin{array}{l}\text { Perubah } \\
\text { an (\%) }\end{array}$} \\
\hline & & Kumulatif & $\begin{array}{l}\text { Rata- } \\
\text { Rata }\end{array}$ & Kumulatif & $\begin{array}{l}\text { Rata- } \\
\text { Rata }\end{array}$ & \\
\hline 1 & $\begin{array}{l}\text { Tenaga kerja } \\
\text { (orang) }\end{array}$ & 32 & 6 & 46 & 9 & 50,00 \\
\hline 2 & $\begin{array}{l}\text { Modal (Rp) } \\
\text { Produksi } \\
\text { (Kg) }\end{array}$ & $\begin{array}{r}3,400,000 \\
, 000\end{array}$ & $\begin{array}{r}680,000 \\
000\end{array}$ & $\begin{array}{r}4,350,000 \\
, 000\end{array}$ & $\begin{array}{r}870,000 \\
000\end{array}$ & 27,94 \\
\hline 3 & $\begin{array}{l}\text { Pendapatan } \\
\text { (Rp) }\end{array}$ & 95.000 & 19.000 & 124.000 & 24.800 & 30,53 \\
\hline 4 & $\begin{array}{l}\text { Keuntungan } \\
(\mathrm{Rp})\end{array}$ & $\begin{array}{r}2,687,000 \\
, 000\end{array}$ & $\begin{array}{r}537,400 \\
000\end{array}$ & $\begin{array}{r}3,480,000 \\
, 000\end{array}$ & $\begin{array}{r}696,000 \\
000\end{array}$ & 29,51 \\
\hline 5 & & $\begin{array}{r}1,530,000 \\
, 000\end{array}$ & $\begin{array}{r}306,000 \\
000\end{array}$ & $\begin{array}{r}2,050,000 \\
, 000\end{array}$ & $\begin{array}{r}410,000 \\
000\end{array}$ & 33,99 \\
\hline
\end{tabular}

Sumber : Data Primer

Tabel 7 menunjukkan bahwa peternak telur ayam ras di Kota Kendari memiliki keberdayaan usaha dengan arah yang meningkat baik dalam aspek penyerapan tenaga kerja, modal, produksi, 
pendapatan maupun perolehan keuntungan.

\section{Faktor-faktor Yang Mempengaruhi Permintaan Telur Ayam Ras}

Berdasarkan deskripsi data faktorfaktor yang mempengaruhi permintaan telur ayam ras (selera konsumen, harga telur ayam ras, harga barang pengganti/ tahu, pendapatan dan jumlah anggota keluarga), maka analisis pengaruh dapat dilakukan dengan menggunakan tabel kerja terlampir. Berdasarkan tabel kerja dimaksud, selanjutnya di analisis dengan menggunakan program komputer (SPSS versi 21.0). Dari lampiran tersebut, selanjutnya dibuatkan rekapitulasi sebagaimana ditampilkan dalam tabel 8 berikut:

Tabel 8. Hasil Analisis Regresi Linear Berganda

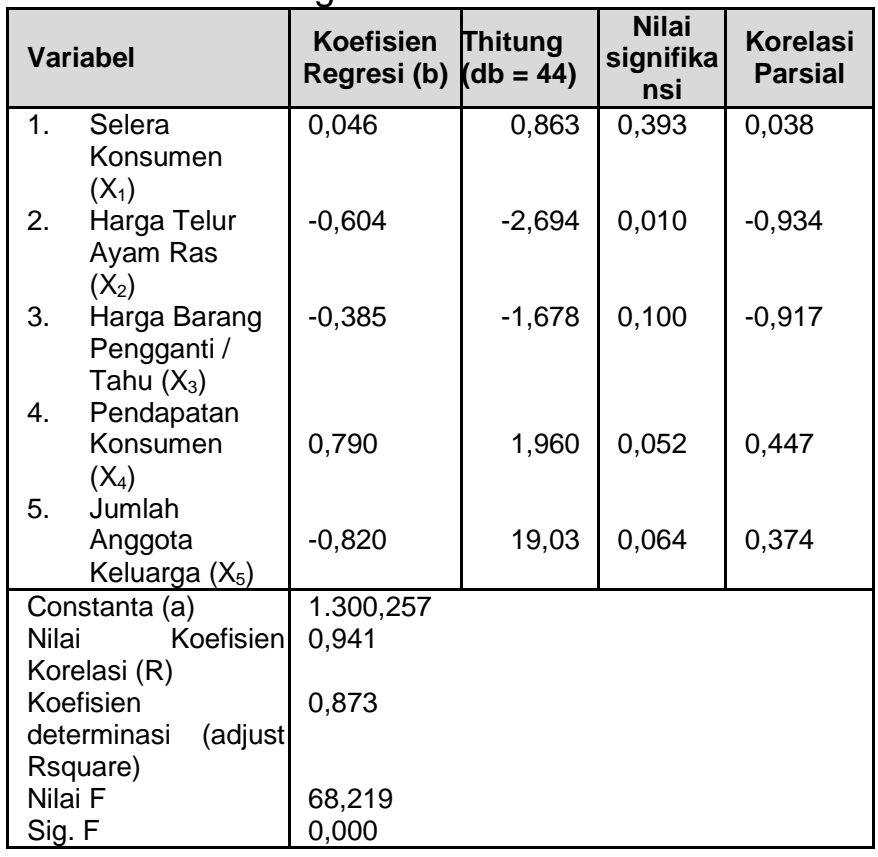

\section{Pengujian Hipotesis}

1. Uji F

Selera konsumen $\left(\mathrm{X}_{1}\right)$, harga telur ayam ras $\left(X_{2}\right)$ harga barang pengganti/ tahu $\left(\mathrm{X}_{3}\right)$, pendapatan konsumen $\left(\mathrm{X}_{4}\right)$ serta jumlah anggota keluarga $\left(X_{5}\right)$ secara simultan berpengaruh signifikan terhadap permintaan telur ayam ras di Kota Kendari (Y). Hal ini ditunjukkan oleh hasil uji $F$ pada tingkat kepercayaan 0,95 atau taraf nyata $\alpha=$ 0,05 dengan nilai $F$ sig. $=0,000<0,05$. Hal ini berarti bahwa variabel selera konsumen, harga telur ayam ras, harga barang pengganti/ tahu, pendapatan konsumen serta jumlah anggota keluarga secara simultan berpengaruh signifikan terhadap permintaan telur ayam ras di Kota Kendari. Artinya bahwa kelima faktor tersebut merupakan faktor-faktor yang signifikan mempengaruhi permintaan telur ayam ras di Kota Kendari.

2. Uji t

Sesuai hasil analisis komputer (SPSS versi 21.0) dapat diketahui bahwa:

a. Selera konsumen $\left(X_{1}\right)$ secara parsial berpengaruh positif namun tidak signifikan terhadap permintaan telur ayam ras di Kota Kendari. Hal ini ditunjukkan oleh hasil uji $\mathrm{t}$ pada tingkat kepercayaan 0,95 atau taraf nyata $\alpha=0,05$ dengan nilai 
probabilitas $=0,393>0,05$. Dengan demikian maka hipotesis yang menyatakan bahwa: selera konsumen berpengaruh signifikan terhadap permintaan telur ayam ras di Kota Kendari tidak dapat diterima (ditolak).

b. Harga telur ayam ras $\left(X_{2}\right)$ secara parsial berpengaruh signifikan demgam arah negatif terhadap permintaan telur ayam ras di Kota Kendari. Hal ini ditunjukkan oleh hasil uji t pada tingkat kepercayaan 0,95 atau taraf nyata $\alpha=0,05$ dengan nilai probabilitas $=0,010<$ 0,05 . Dengan demikian maka hipotesis yang menyatakan bahwa: harga telur ayam ras berpengaruh signifikan terhadap permintaan telur ayam ras di Kota Kendari dapat diterima. Harga barang pengganti/tahu $\left(X_{3}\right)$ secara parsial berpengaruh negatif namun tidak signifikan terhadap permintaan telur ayam ras di Kota Kendari. Hal ini ditunjukkan oleh hasil uji t pada tingkat kepercayaan 0,95 atau taraf nyata $\alpha=0,05$ dengan nilai probabilitas $=0,100>0,05$. Dengan demikian maka hipotesis yang menyatakan bahwa: harga barang pengganti/ tahu berpengaruh signifikan terhadap permintaan telur ayam ras di Kota Kendari tidak dapat diterima (ditolak).

c. Pendapatan konsumen $\left(\mathrm{X}_{4}\right)$ secara parsial berpengaruh positif dan signifikan terhadap permintaan telur ayam ras di Kota Kendari. Hal ini ditunjukkan oleh hasil uji $\mathrm{t}$ pada tingkat kepercayaan 0,95 atau taraf nyata $\alpha=0,05$ dengan nilai probabilitas $=0,052 \leq 0,05$. Dengan demikian maka hipotesis yang menyatakan bahwa: pendapatan konsumen berpengaruh signifikan terhadap permintaan telur ayam ras di Kota Kendari tidak dapat diterima.

d. Jumlah anggota keluarga $\left(X_{5}\right)$ secara parsial berpengaruh negatif namun tidak signifikan terhadap permintaan telur ayam ras di Kota Kendari. Hal ini ditunjukkan oleh hasil uji t pada tingkat kepercayaan 0,95 atau taraf nyata $\alpha=0,05$ dengan nilai probabilitas $=0,064>$ 0,05 . Dengan demikian maka hipotesis yang menyatakan bahwa: jumlah anggota keluarga berpengaruh signifikan terhadap permintaan telur ayam ras di Kota Kendari tidak dapat diterima (ditolak). 


\section{Pembahasan Hasil Penelitian}

Faktor-faktor yang mempengaruhi permintaan telur ayam ras di Kota Kendari

\section{a. Pengaruh Selera Konsumen Terhadap Permintaan}

Berdasarkan hasil penelitian menunjukkan bahwa selera konsumen berpengaruh positif namun tidak signifikan terhadap permintaan telur ayam ras di Kota Kendari. Ini berarti bahwa selera konsumen bukan merupakan faktor yang signifikan dalam menentukan atau mempengaruhi permintaan telur ayam ras di Kota Kendari.

\section{b. Pengaruh Harga Telur Ayam Ras Terhadap Permintaan}

Berdasarkan hasil penelitian menunjukkan bahwa harga telur ayam ras berpengaruh signifikan dengan arah negatif terhadap permintaan telur ayam ras di Kota Kendari. Ini berarti bahwa apabila harga telur ayam ras meningkat maka permintaan konsumen terhadap telur ayam ras akan menurun.

\section{c. Pengaruh Harga Barang Pengganti/ Tahu Terhadap Permintaan}

Berdasarkan hasil penelitian menunjukkan bahwa harga barang pengganti/ tahu berpengaruh negatif dan tidak signifikan atau dapat dikatakan tidak berpengaruh terhadap permintaan telur ayam ras di Kota Kendari. Ini berarti bahwa apabila harga tahu meningkat maka tidak akan mempengaruhi permintaan telur ayam. Kalaupun terjadi penurunan hanya sedikit saja, dalam artian tidak signifikan.

\section{d. Pengaruh Pendapatan Konsumen Terhadap Permintaan}

Berdasarkan hasil penelitian menunjukkan bahwa pendapatan konsumen berpengaruh positif dan signifikan terhadap permintaan telur ayam ras di Kota Kendari. Ini berarti bahwa peningkatan pendapatan konsumen akan mempengaruhi permintaan telur ayam ras secara signifikan.

\section{e. Pengaruh Jumlah Anggota Keluarga Terhadap Permintaan}

Berdasarkan hasil penelitian menunjukkan bahwa jumlah anggota keluarga berpengaruh negatif namun tidak signifikan terhadap permintaan telur ayam ras di Kota Kendari. Ini berarti bahwa semakin banyak anggota keluarga maka permintaan terhadap telur ayam ras semakin menurun namun penurunan tersebut tidak signifikan.

Keberdayaan Peternak Ayam Ras di Kota Kendari

Berdasarkan hasil penelitian diketahui bahwa keberdayaan peternak dalam hal ini tercermin pada perubahan tenaga kerja, modal, produksi telur ayam ras, pendapatan/ hasil penjualan, dan perubahan keuntungan.

\section{Hubungan Permintaan dengan Keberdayaan Peternak Ayam Ras di Kota Kendari}

Hubungan perpemintaan denan keberdayaan peternak ayam ras di Kota Kendari dalam hal ini dapat dijelaskan 
secara konseptual bahwa semakin meningkatnya permintaan konsumen terhadap telur ayam ras tentunya aka ada kaitannya dengan keberdayaan peternak. Apabila permintaan meningkat maka peternak pasti akan berusaha meningkatkan produksinya. Jika produksi ditingkatkan pasti membutuhkan peningkatan modal termasuk tenaga kerja. Peningkatan produksi tentunya diharapkan dapat memacu peningkatan hasil penjualan dan meningkatnya hasil penjualan pasti akan meningkatkan keuntungan.

Pemikiran konseptual tersebut dapat diperkuat melalui analisa statistik khususnya koefisien korelasi product moment. Dengan menggunakan program aplikasi komputer (SPSS versi 21.0) terlampir (lampiran 10), maka dapat diketahui bahwa :

1. Permintaan telur ayam ras berhubungan dengan keberdayaan peternak apabila ditinjau dari aspek perubahan tenaga kerja yang ditandai dengan nilai koefisien korelasi sebesar 0,028 (korelasi positif dengan kriteria sangat lemah).

2. Permintaan telur ayam ras berhubungan dengan keberdayaan peternak apabila ditinjau dari aspek perubahan modal yang ditandai dengan nilai koefisien korelasi sebesar 0,094 (korelasi positif dengan kriteria sangat lemah).
3. Permintaan telur ayam ras berhubungan dengan keberdayaan peternak apabila ditinjau dari aspek perubahan produksi yang ditandai dengan nilai koefisien korelasi sebesar 0,075 (korelasi positif dengan kriteria sangat lemah)..

4. Permintaan telur ayam ras berhubungan dengan keberdayaan peternak apabila ditinjau dari aspek perubahan pendapatan yang ditandai dengan nilai koefisien korelasi sebesar 0,070 (korelasi positif dengan kriteria sangat lemah).

5. Permintaan telur ayam ras berhubungan dengan keberdayaan peternak apabila ditinjau dari aspek perubahan keuntungan yang ditandai dengan nilai koefisien korelasi sebesar 0,048 (korelasi positif dengan kriteria sangat lemah).

\section{KESIMPULAN DAN SARAN}

\section{Kesimpulan}

Berdasarkan hasil penelitian dan pembahasan maka dapat ditarik kesimpulan sebagai berikut :

1. Faktor selera konsumen, harga telur ayam ras, harga barang pengganti/ tahu, pendapatan konsumen dan jumlah anggota keluarga secara bersamaan berpengaruh signifikan terhadap permintaan telur ayam ras di Kota Kendari.

a. Selera konsumen secara parsial berpengaruh positif namun tidak 
signifikan terhadap permintaan telur ayam ras di Kota Kendari.

b. Harga telur ayam ras berpengaruh negatif dan signifikan terhadap permintaan telur ayam ras di Kota Kendari. Maksudnya semakin tinggi harga telur ayam ras maka akan menurunkan permintaan konsumen.

c. Harga barang pengganti/tahu secara parsial berpengaruh negatif namun tidak signifikan. Maksudnya peningkatan harga tahu tidak akan mempengaruhi permintaan telur ayam ras.

d. Pendapatan konsumen berpengaruh positif dan signifikan terhadap permintaan telur ayam ras di Kota Kendari. Maksudnya peningkatan pendapatan dapat meningkatkan permintaan telur ayam ras.

e. Jumlah anggota keluarga secara parsial berpengaruh negatif namun tidak signifikan terhadap permintaan telur ayam ras di Kota Kendari. Maksudnya peningkatan jumlah anggota keluarga akan menurunkan jumlah permintaan tetapi tidak signifikan.

2. Peternak ayam ras di Kota Kendari semakin meningkat keberdayaannya baik dalam aspek perubahan tenaga kerja, modal, produksi, pendapatan maupun keutungan.
3. Permintaan telur ayam ras berhubungan secara positif dengan keberdayaan peternak ayam ras di Kota Kendari walaupun hubungan tersebut termasuk dalam kriteria hubungan sangat lemah.

\section{Saran}

Berdasarkan kesimpulan tersebut maka disarankan beberapa hal untuk dilaksanakan sebagai berikut :

1. Sebaiknya peneliti yang akan datang dapat mengembangkan hasil penelitian ini dengan menambahkan variabel perkiraan harga dimasa yang akan datang, distribusi pendapatan termasuk usaha-usaha sampingan yang dilakukan oleh konsumen untuk meningkatkan pendapatannya.

2. Hasil penelitian ini dapat dikembangkan dengan melibatkan jumlah responden yang lebih besar termasuk variasi status pekerjaan yaitu bisa ditambahkan keluarga sopir, nelayan, buruh bangunan, petani, TNI, Polri serta karyawan BUMN. Disamping itu, lokasi penelitian dapat diperluas pada tinggkat provinsi sehingga diperoleh data peternak yang lebih besar.

3. Bagi pemerintah kiranya dapat menjadi mediator dalam membantu peternak untuk mengembangkan usahanya terutama yang berkaitan dengan akses permodalan dan bimbingan teknis.

4. Bagi peternak ayam ras sebaiknya membentuk asosiasi peternak agar 
memudahkan dalam melakukan

pembinaan oleh instansi teknis (Dinas

Peernakan).

\section{DAFTAR PUSTAKA}

Abdul Ghafoor, Hammad Badar, Maqsood Hussain and Naeem Tariq. 2010. An Empirical Estimation of the Factors Affecting Demand and Supply of Poultry Meat. Di download dari http://www.pvj.com.pk

Adi, I. R. 2012. Pemberdayaan, Pengembangan Masyarakat dan Intervensi Komunikasi (Pengantar pada Pemikiran dan Pendekatan Praktis). Lembaga penerbit Fakultas ekonomi Universitas Indonesia, Jakarta.

Alexander Sinaga, Salmiah dan Sinar Indra Kesuma. 2009. Faktor-Faktor yang Mempengaruhi Permintaan Daging Ayam Kampung di Kecamatan Siantar Barat, Kota pematang Siantar. Di download dari http://www.repository.usu.ac.id

Alfred W. Stoner. 2010. Manajemen. Erlangga, Jakarta.

Anggorodi, R. 2010. Kemajuan Mutakhir Dalam IImu Makanan Ternak Unggas. Universitas Indonesia Press. Jakarta

Anoraga P. 2008. Manajemen Bisnis. Rineka Cipta, Jakarta.

Antara, M. 2010. Metodologi Penelitian Bisnis. Bahan Ajar Program Magister Agribisnis Program PascaSarjana Universitas Udayana, Denpasar.

Departemen Pertanian. 1997. Agribisnis Ayam Buras. Balai Pengkajian Teknologi Pertanian, Ungaran.

2001. Pembangunan Sistem agribisnis Sebagai
Penggerak

Ekonomi

Nasional.Pertama. Jakarta.

Djanah, D. 2010. Beternak Ayam. CV. Yasaguna. Cetakan kedua, Surabaya.

Downey, W. D. dan S.P. Erickson. 2012. Manajemen Agribisnis. Edisi Kedua. R. Ganda S. dan A. Trait (Penterjemah), Terjemahan dari : Agribusiness Management. Erlangga, Jakarta.

Fitrini, Andri dan A.N. Yanti. 2006. Analisis Permintaan Telur Ayam Ras di Kota Padang dan Faktor Yang Mempengaruhinya. Di download dari http://www.jpi.faterna.unand.ac.id

Ghozali, Imam. 2012. Aplikasi Analisis Multivariate Dengan Program SPSS. Edisi Keempat, Penerbit Universitas Diponegoro.

Gumbira-Sa'id. E. 2010. Wawasan, Tantangan dan Peluang Agrotechnopreneur Indonesia. PT. Penerbit IPB Press, Bogor.

Gujarati. 2010. Ekonometrika Dasar. Erlangga, Jakarta.

Hardinsyah dan Arifin dalam Kemalawaty. 2008. Analisa Konsumsi pangan Sumber Protein Hewani di Provinsi Aceh. Fakultas Pertanian IPB, Bogor.

Hardi, P. 2010. Interaksi Antara Bangsa Itik dan Kualitas Ransum Pada Produksi dan Kualitas Telur Itik Lokal. Balai Penelitian Ternak. Bogor.

Hastang, Veronica Sri Lestari, Arie Prayudi. 2011. Beberapa Faktor Yang Mempengaruhi Jumlah Permintaan Telur Ayam Ras Oleh Konsumen di Pasar Pa'baeng-Baeng, Makassar. Di download dari http://www.repository.unhas.ac.id 
Isbandi Rukminto Adi. 2011. Pemberdayaan, Pengembangan Masyarakat, dan Intervensi Komunitas. LPFE Universitas Indonesia, Jakarta.

Jonathan Sarwono. 2007. Analisis Jalur Untuk Riset Bisnis Dengan SPSS. Penerbit Andi. Yogyakarta.

Kadaria. 2008. Pengantar Teori Ekonomi Makro. Bina Aksara, Jakarta.

Kast. Fremont. E dan Rosensweig. 2010. Organisasi dan manajemen. Terjemahan Yasin. Bina Aksara, Jakarta.

Lailatul Mubarokah. 2012. Analisis FaktorFaktor Yang Mempengaruhi Permintaan Telur Asin di Kecamatan Banyubiru Kabupaten Semarang. Di download dari http://www.core.ac.uk

Leftwich, Richard H., 2009. Mikro Ekonomi. PT. Bina Aksara, Jakarta.

Lestari, P, I. 2009. Kajian Supply Chain Management:Analisis

RelationshipMarketing antara Peternakan Pamulihan Farm dengan Pemasok dan Pelanggannya. Institut Pertanian Bogor. Bogor.

Mohamed Abbas Mohamed Ali Ibrahim. 2011. The Determinants of International Tourism Demand for Egypt: Panel Data Evidence. Di download dari http://www.researchgate.net

Nanang Febrianto, Budi Hartono, dan Hari Dwi Utami. 2013. Analysis of the Demand for Eggs in City Of Malang. Di download dari http://www.iosrjournals.org

Nicholson Walter. 2009. Teori Ekonomi Mikro II. UI-Press, Jakarta.
North, M.O. And D.D Bell. 2010. Commercial Chicken Production Manual. 4th Edition. Published By Van Nostrand Reinhald, New York.

Onny S Priyono dan AMW Pranarka. 2006. Pemberdayaan; Konsep, Kebijakan dan Implementasi. Centre for Strategic and Interenasional Studies, Jakarta.

Paulo Freire. 2012. Pedagogy of the oppressed. Herder and Herder, New York.

Petersen. 2007. Supplemental methionine and urea for gestating beef cows consuming low quanty forage diets. J. amin. Sci. 85:731-736

Prathama Raharja. 2010. Teori Ekonomi Mikro. BPFE., UGM., Yogyakarta.

Rasyaf, M. 2011. Pengelolaan Produksi Telur. Kanisius, Yogyakarta.

Resti Wahyuningsih. 2008. Analisis Permintaan Telur Ayam di Jawa Timur. Di download dari http://www.lkusrina.staff.gunadarma. ac.id

Roger D. Blackwell, dan Paul W. Miniard. 2009. Perilaku Konsumen. Edisi Keenam. Jilid 1. Penerbit Binarupa Aksara. Jakarta.

Romanoff, A. I. dan A. J. Romanoff. 2008. The Avian Egg. Jhon Willey and Sons. Inc, New York.

Santoso, Singgih, 2000. SPSS, Mengolah Data Statistik Secara Profesional. PT. Elex Media Komputindo, Jakarta.

Saragih, B. 2011. Suara Dari Bogor : Membangun Sistem Agribisnis. PT. Pustaka Wirausaha Muda, Bogor. 
Sarwono, B. 2009. Pengawetan dan Pemanfaatan Telur. PT. Swadaya, Jakarta.

Shanty Effly Siregar. 2012. Analisis Permintaan Daging Ayam Broiler pada Konsumen Rumah Tangga di Kelurahan Pisangan Timur Kecamatan Pulogadung Jakarta Timur. Di download dari http://www.core.ac.uk

Siagian, R. 2008. Pengantar Manajemen Agribisnis. Gadjah Mada University Press. Yogyakarta.

Soekartawi. 2010. Agribisnis Teori dan Aplikasinya. PT. Raja Grafindo Persada, Jakarta.

Sudaryani, T. dan H. Santosa. 2009. Pembibitan Ayam Ras. Penebar Swadaya, Jakarta.

Sugiono. 2010. Statistika Untuk Penelitian. Alfabeta, Bandung.

Sukirno, S. 2012. Pengantar Teori Mikro Ekonomi. Edisi 2, PT. Raja Grafindo Persada, Jakarta.

Sumarni dan Nan Djuarnani. 2010. Diktat Penanganan Pasca Panen Unggas. Departemen Pertanian. Balai Latihan Pertanian, ternak, Ciawi Bogor.

Suparta, N. 2011. Pendekatan Holistik Membangun Agribisnis. CV Bali Media Adhikarsa, Denpasar.

Suryana. 2012. Membangun Ketahanan Pangan Regional Melalui Pengembangan Sistem dan Usaha Agribisnis. Dalam:Prosiding Lokakarya Pengembangan Usahatani Terpadu Berwawasan Agribisnis Menunjang Pemanfaatan Sumberdaya Pertanian Jawa Barat. Balai Pengkajian Teknologi Pertanian Jawa Barat, Bogor.

Suryanto, B. 2009. Peran Usahatani Ternak Ruminansia Dalam Pembangunan
Agribisnis berwawasan lingkungan. Pidato pengukuhan Guru Besar dalam IImu Manajemen usahtani. Undip Semarang 6 Oktober. Bp Univ. Diponegoro Semarang.

Sulistiyani, Ambar Teguh. 2009. Kemitraan dan Modul-modul Pemberdayaan. Gava Media, Yogyakarta.

Tillman, dkk. 2006. Ilmu Makanan Ternak Dasar. Gajah Mada University Press, Yogyakarta.

Umar, M.M, Sundari S, dan A.M Fuah. 2010. Kualitas Fisik Telur Ayam Kampung Segar di Pasar Tradisional, Swalayan, dan Peternak di Kotamadya Bogor. Institut Pertanian Bogor. Bogor. 